Arab Univ. J. Agric. Sci., Ain Shams Univ., Cairo, Egypt
29(2), 505-517, 2021
Website: http://ajs.journals.ekb.eg

\title{
A Study on Pesticide Sprayer Powered by Solar Energy Appropriate for Small Farms
}

Ahmed ME Abdel Rahman*, Abdel-Fadil GM Kabany, Waleed K El-Helew Agric. Engineering Dept, Fac of Agric, Ain Shams Univ, P.O. Box 68 Hadyek Shoubra 11241, Cairo, Egypt

*Corresponding author: Ahmed_Mesbah@agr.asu.edu.eg

Received 24 March, 2021

Accepted 2 July, 2021

\begin{abstract}
The study was conducted on a knapsack sprayer powered by a DC motor through a 12 $\mathrm{V}$ lead acid battery charged from a solar panel (photovoltaic) directed to sun rays. The system was installed and tested in the western desert on a small-scale farm at Fraf ra Oasis (New valley). This study aimed to evaluate and develop a knapsack sprayer powered by a solar energy for overcoming operator fatigue and shortage of traditional energy in Egypt's western desert. The experiments were conducted during the period which starts in August 2019 till February 2020. The main parts of the system consist of photovoltaic (PV) or solar cells, charger controller, rechargeable battery, and DC motor speed control with dimmer and pump which was attached with a tank 20 liters capacity for sucking and pressurizing the liquid to the boom of the sprayer through a flexible hose. The main results of experiments were as follows: The time for recharging the battery completely was found 330 minutes ( 5.5 hours) to charge completely from $10.55 \mathrm{~V}-13.85 \mathrm{~V}$, with current intensity 1.67 Ampere. The battery discharge time was varied due to drop the battery voltage from $13.85-10.55$ Volts. Depending on the motor speed, which is the time for discharging the battery was found $4-9$ hours, when motor pulled $0.85-1.85$ Amps at $2000-3400 \mathrm{rpm}$ and this time at deferent speed is enough to spray area $3-6.82$ fed/day "day work $=6$ hours" with application rate 67
\end{abstract}

- $104.71 /$ fed. The number of droplets and the area coverage percentage ranges from $30-$ 146.33 drops and $13.96-27.97 \%$ for one $\mathrm{cm}^{2}$ of simulator targets at a speed ranging from $2000-3400 \mathrm{rpm}$, respectively.

Keywords: A knapsack sprayer, Solar energy, DC motor, Charger controller, Battery charging time, Discharging time

\section{Introduction}

Chemicals applications are the most important operations in agricultural production. Manually operated knapsack sprayers are commonly used by Egyptian small farms to apply pesticides, herbicides, fungicides, and other compounds. This type is easy to operate and inexpensive. The operator uses both his two hands to operate the sprayer, one of them for moving the handle upward and downward continuously, and the other hand directs the spray on the target location. The operator exerts effort while he pumping by handle. After while he suffering fatigue and discomfort of the operator arm. Consequently, he needs rests many times resulting in poor performance due to reduced productive time. In addition, manually pumping operation gives more variation in liquid pressure and results in application difference which affects distribution uniformity. Battery powered pumps charged by electricity can be used instead of handle. An air-carrier sprayer powered by a small 2 -stroke engine 
fueled by gasoline-oil mixture can also be used in spraying agricultural materials. In some Egypt's rural areas, there is a shortage in supplying electricity and fuels. Because of Egypt lies on solar belt which is exposed to a large amount of solar radiation, solar energy is one solution forgenerating electricity by solar panels. (Ashutosh et al 2019) referred to that Sustainable power source is generally characterized as power that originates from durable assets. The solar is the most considerable and limitless supply of energy. As solar energy is one of the most important non-conventional sources of power. This energy is environmental friendly, which is a mainly loo from pollutants. Solar energy get from the sun is harvested at the solar panel which made of photovoltaic cells and transforms energy from photon to electric. These cells are made up of silicon semiconductor. Solar powered is utilized to store electric vitality or charge the battery from the sunlight based vitality and the battery charged is utilized to work DC motor. The attributes of using solar PV for operating pump compared with gasoline or diesel pump were low maintenance, easy installation, long age of default and environmentally friendly (no noisiness and no exhaust gases). While defects were big costs and repairs often require trained technicians (Abu-Aligah 2011). Storage systems like Batteries are used for the electricpower tankage because of stand-alone photovoltaic structures for the duration of no sunlight (Xing et al 2011). The main function of the charge controller protects the battery from over discharging and charging also it is work efficiency depend up on the amount of current used for charging the process, clear the level of the oscillations in the charging current, the fluctuations in the temperature during charging voltage (Abu Eldahab et al 2016). Spraying of pesticides is a necessary assignment in agriculture for preventing the vegetation from insects. Farmers still use ordinary methods to liquid fertilizers or spray pesticides, such as hand held knapsack or self-power sprayer. The use of a guide knapsack sprayer leads to a limit in worker productivity, a reduce in work and pro- duction efficiency. Consequently, the distribution of pesticides or liquid fertilizers is nonsystemic all through the area and relies upon the experience of the worker (Aboegela et al 2019). Solar sprayer also should be without difficulty utilized in remoted places. The purpose of the proposed model is that if the utilization of electric powered backpack sprayer can optimize the battery duration of those equipment. So that this work had aimed to increase and assessment a device to ease battery charging in more conditions of field and optimizing its period in electric backpack sprayers using photovoltaic panels, by using of modern technologies, such as multiple cells with unique bands and also mild concentrators, it may be possible to enhance the efficiency of photo voltaic panels (Meral and Dincer 2011). Imaging analyzers are spatial model strategies comprising a light source, a digital camera, and a computer with the image including photograph acquisition and technology software. The small droplet sizes, the excessive speeds of the ejected spray droplets accomplish such a challenge after using imaging methods for spray characterization. Imaging techniques are based totally on the interferometric method (Kannaiyan and Sadr 2014). Taking images used for measuring the droplets depositing on collector such aplastic sheets to counts area coverage as percentage, liquid density on the target and droplets number per square area (Fox et al 2003). For quality spraying of pesticides and economically viable, it should meet the technical, functional, operational and structural requirements so as to avoid clogging, a mesh filter will be placed before the nozzle in head to anticipate clogging (Vinay 2016). This study is to evaluate and develop a knapsack sprayer powered by a solar energy for overcoming operator fatigue and shortage of traditional energy in Egypt's western desert. So that we are using solar power and charged battery for operation, because of easy to construction, easy to clean \& maintain and suitable for small farms, in order to preserve the environment and reduce the negative effects of climate change. 


\section{Materials and Methods}

The main goal of this study is to evaluate the pesticide sprayer, which is powered by a $12 \mathrm{v}$ battery charged from photovoltaic solar energy. The following materials and methods were used to achieve this goal.

\subsection{Experimental location}

Experiments were conducted at ElFrafra (New Valley, Egypt). The longitude and latitude of the experiment site are $29^{\circ} 30^{\prime} 01.2^{\prime \prime}$ E, $25^{\circ} 15^{\prime} 25.2^{\prime \prime} \mathrm{N}$, respectively.

\subsection{General principle of spraying operation}

Spraying operation with an electrical sprayer, the first unit of the proposed system is the energy conversion unit. Solar energy obtained by the sun is converted into electrical energy using solar panels by the photovoltaic effect. The motor is connected to a battery through connecting wires. Between this mechanical circuit breaker switch is provided to starts and stops the working of the motor. The energy conversion is given to the charge battery through a charge controller. The charge controller limits the rate at which electric current is added to the battery and prevents overcharging and protecting against overvoltage.

\subsection{Main components of the system}

Fig 1 illustrates that the operation stages of the solar-powered sprayer as follows:

- Generating the electric power from the PV panel.

- Charging the battery for storing the energy.

- A charged battery is placed in a small box fixed on rear side of the plastic tank then connecting to the terminal with an electrical circuit to start the operation.

- Filling the tank with liquid and recommended dose then starting operation.
Fig 2 shows the proposed system, which is designed to charge the battery then take the battery to drive the DC motor. The system consisted of the following elements: photovoltaic generator, battery charger, leadacid battery, potentiometer control on the rpm, DC motor, pump, flexible plastic hose with a metal lance and boom sprayer with three nozzles.

2.3.1 The generating unit: consists of two main parts were describes as follow:

- Solar panel: solar power is of renewable energy available, and it can be used in several forms to help power applications. Solar powered photovoltaic (PV) panels convert the sun's rays into electricity by exciting electrons in silicon cells using the photons of light from the sun, this electricity can be used to supply the energy to battery as presented in Fig 3.

- Charge controller: the charge controller regulator is also known as voltage regulator or charge/discharge controller. The regulator prevents overcharging or over discharging. It's disconnected charge between the panel and the battery to avoid overcharging to improve their lifetime.

\subsubsection{The battery}

Fig 4 illustrates battery that is a significant part in the model that converts chemical energy to electrical energy. This is a $12 \mathrm{~V} / 8 \mathrm{Ah}$ lead acid battery.

\subsubsection{The pump}

The maximum flow rate and maximum pressure for selecting pump were 3 liters/minute and $0.45 \mathrm{MPa}$, respectively. This pump has two outlets. It develops suction with a strainer attached at the bottom of the tank. When connected to a battery and pumps the liquid from the tank via oneoutlet and supplies to the boom sprayer through the other outlet as showen in Fig 5. 


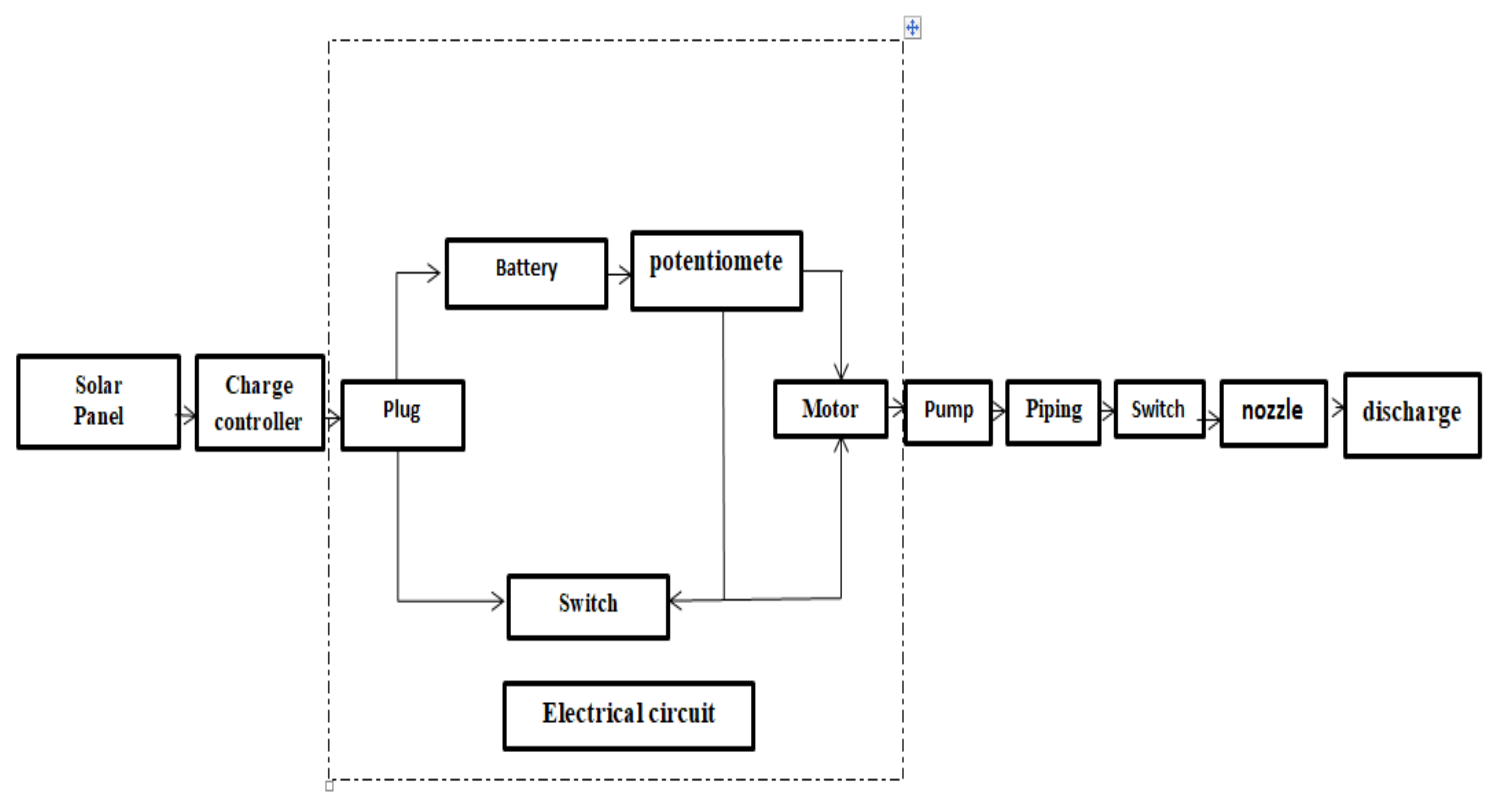

Fig 1. The four stages and main components of the operating system

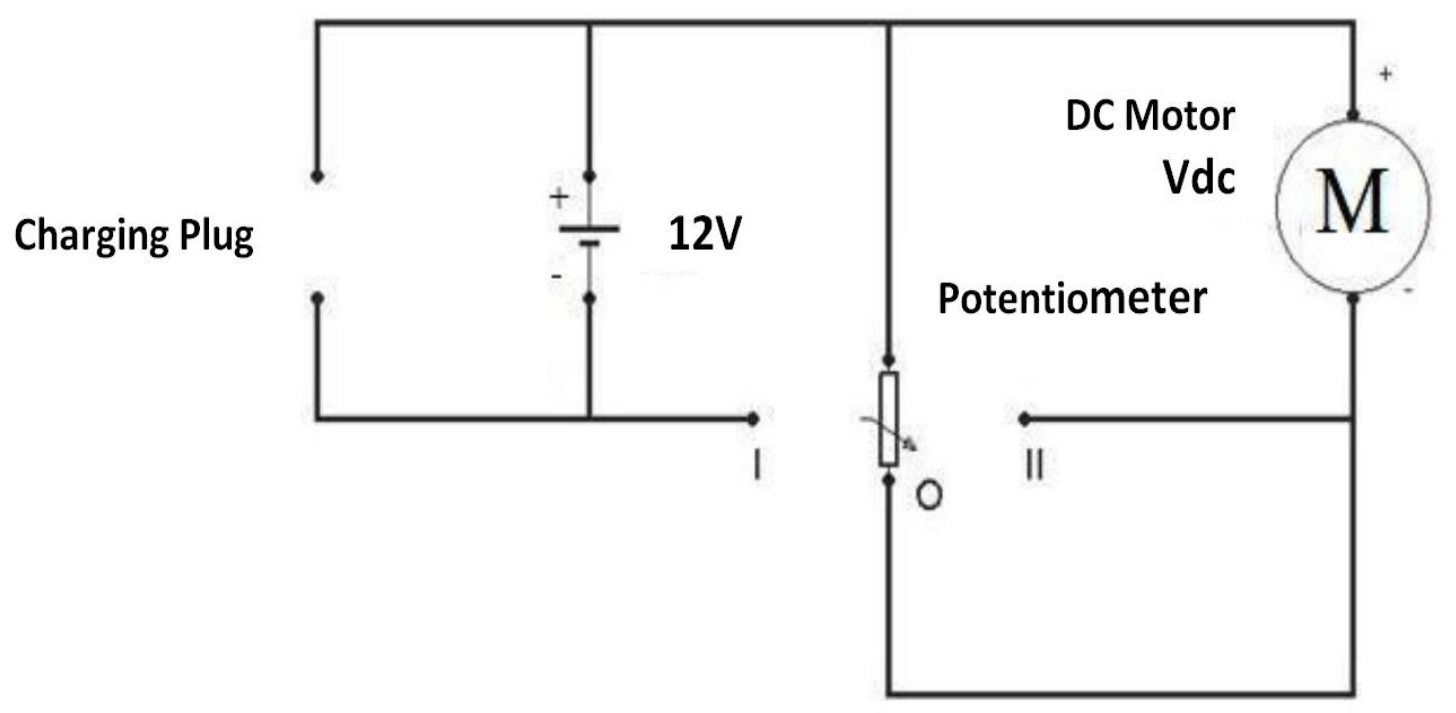

Fig 2. Electric circuit for controlling speed motor(rpm) 


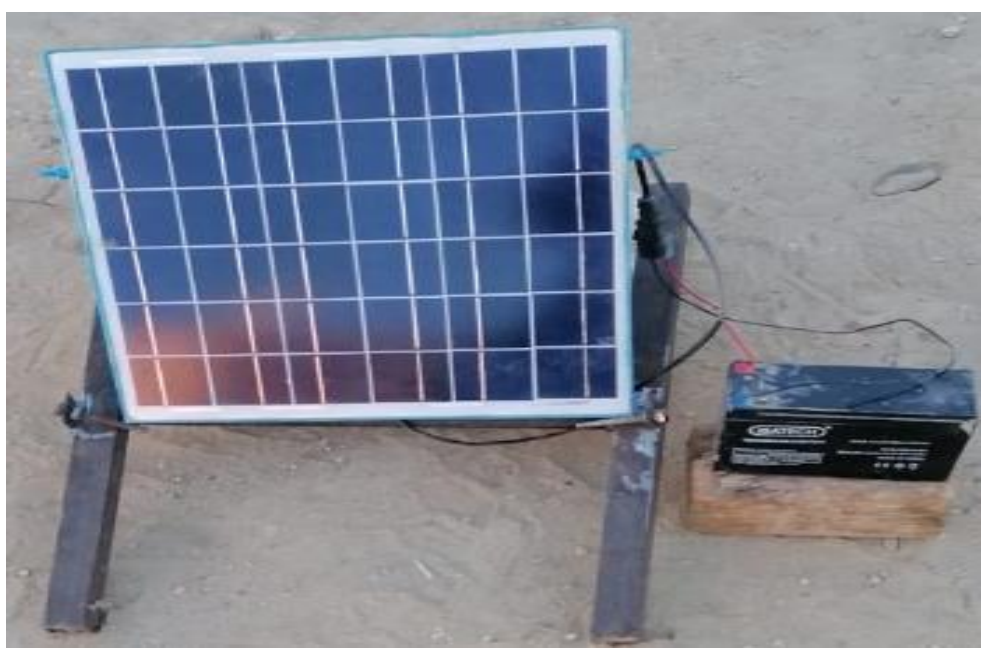

Fig 3. Photographic view of Solar Panel with the battery fixed in the site with slope angle $26^{\circ}$
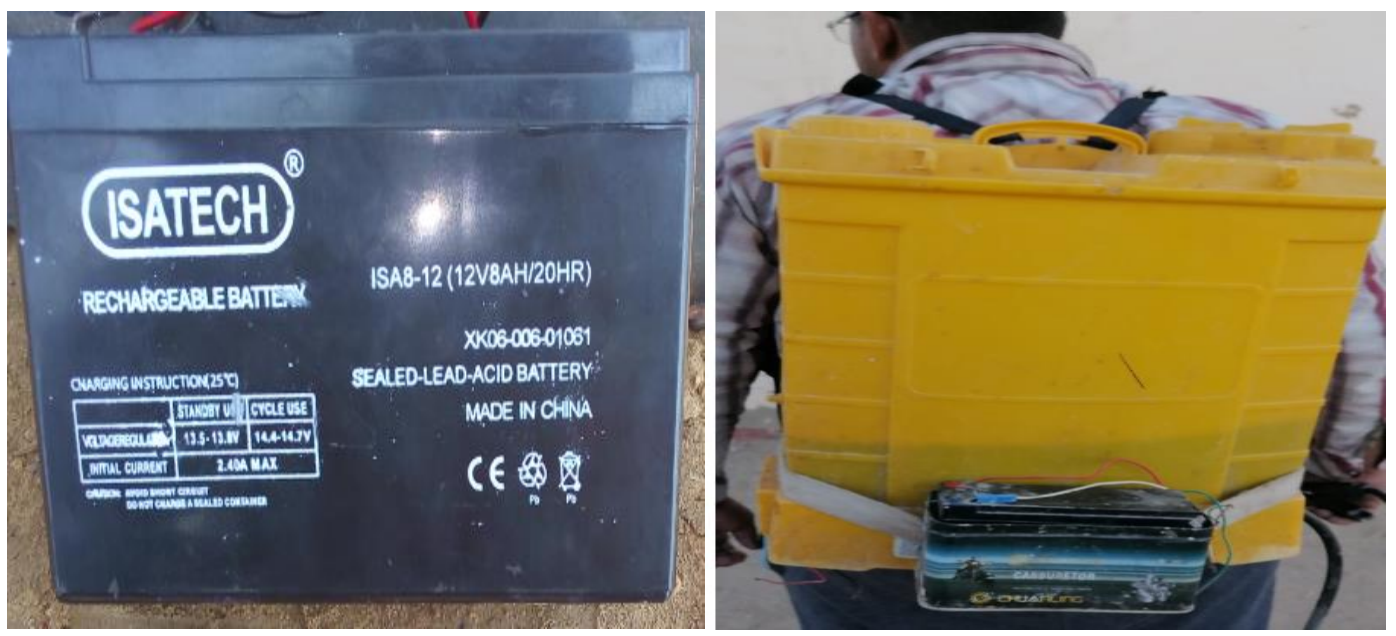

Fig 4. Photographic view of the battery installed in the rear end of sprayer

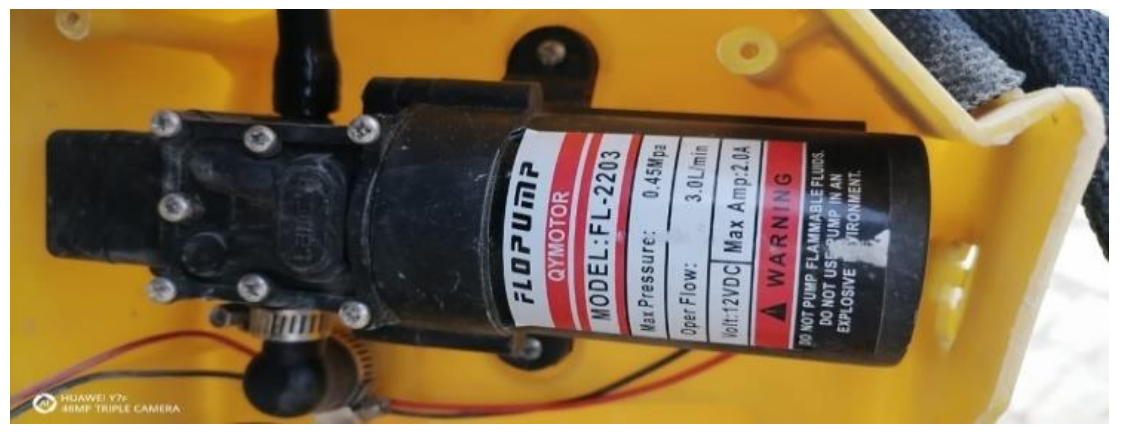

Fig 5. A photographic view of the pump fixed with two brackets in the sprayer frame 


\subsubsection{Multi-nozzle boom sprayer}

The flat fan nozzles were used in the steel boom sprayers with three nozzles. The distance between nozzles is $35 \mathrm{~cm}$, to maintain good distribution spray pattern as showen in Fig 6. During spray calibration, the nozzles were checked to ensure uniform discharge from each one, the same type of nozzles was installed at all points of the boom, and hydraulic spray nozzle was used in more application, in association with other parameters such as height above the target and traveling speed. The main previous components specs of the system were illustrated in Table 1.

\subsection{Studied parameters}

\subsubsection{Rotating speed}

The electrical motor powered by rechargeable battery was used its 2000, 2700 and $3400 \mathrm{rpm}$ measured with tachometer and it's affecting on the flow rate of spray, forward labor speed and there are influencing whoever.

- The ratio of area coverage as a percentage for square area and number of droplets (Droplet No. $/ \mathrm{cm}^{2}$ ).

- The flow rate of the nozzles in the multi-nozzle boom sprayer.

- The nozzle spray angle of the flat fan nozzles in the multi-nozzle boom sprayer.

- Performance rate.

\subsubsection{Testing State of the selected battery during recharging and discharging}

- Testing state of the battery and fully recharged time using the photovoltaic cells.

- Testing state of the battery and discharging time with connected motor-powered at 0.85 , 1.40 and 1.85 Amps.

\subsection{Laboratory experiment}

This experiment was carried out in laboratory of agricultural engineering department, Faculty of Agriculture, Ain Shams University and laboratory conditions were a temperature of $18^{\circ}$ a relative humidity of $65 \%$ and procedures were as follows:

- Plastic cards as artificial target were used to receive the deposited spray from the nozzles.

- The cards were placed in five arranged numbered samples. The dimensions for each sample were $90 \mathrm{~mm} \times 80 \mathrm{~mm}$ (Wolf 2003).

- Plastic cards were distributed on the ground in three rows, every row was contained five samples with an on-row-spacing $40 \mathrm{~cm}$ and row spacing was $35 \mathrm{~cm}$.

- At the beginning of each operation, precaution was taken to make sure that all parts for the sprayer were adjusted. Measurements were taken after 3 minutes from spraying start to reach the conditions for steady state.

- The average linear speed of the operator was $0.71 \mathrm{~m} / \mathrm{s}$. After spraying, every sample card was imaged with height resolution camera both of brand and model are Canon EOS800, to evaluate the characteristic of deposition such as an area of coverage and number of spray deposits. After acquisition 15 sample images, ImageJ is a Java-based image - processing program used for the analy sis of images as illustrated in Fig 7 (Theriault et al 2001).

- The experiment repeated in three replicated with two factors speed motor $(2000,2700$ and $3400 \mathrm{rpm}$ ) and lateral distance for boom sprayer movement.

2.6 Field experiment test and design calculation for selection of the main component for electrical sprayer

\subsubsection{Battery charging time}

The current produced by the solar panel (A) was calculated by knowing the maximum power $(\mathrm{P})$ of the solar panel and the voltage rating $(\mathrm{V})$ of the battery that is given from Equation (1) (Abdulmumuni et al 2020).

Current produced by the solar panel $(\mathrm{A})=$ $\frac{\text { Total Maximum Power }(\mathrm{P})}{\text { Voltage rating }(\mathrm{V})}$ 


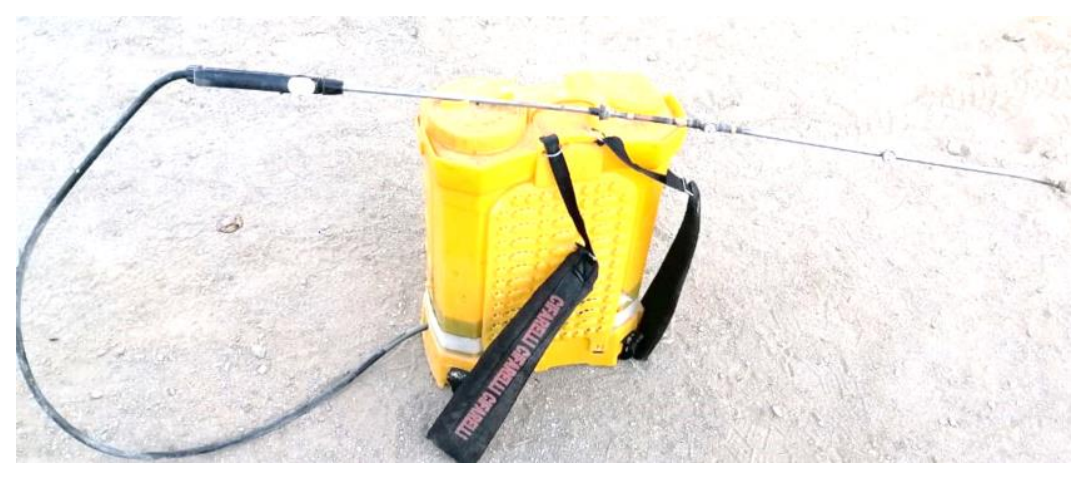

Fig 6. Photographic views of boom sprayer with lance multi-orifices

Table 1. Main components specs of the system

\begin{tabular}{|c|c|c|c|}
\hline $\mathbf{S} / \mathbf{N}$ & Components & Property & Specification \\
\hline 1 & Solar Panel & $\begin{array}{l}P_{\max } \\
V_{\text {oc }} \\
V_{\text {mpp }} \\
I_{\text {mpp }} \\
\text { No. of cells } \\
\text { Weight } \\
\text { Length } \times \text { Width } \times \text { Thickness }\end{array}$ & $\begin{array}{l}20 \text { wp } \\
21.5 \text { volts } \\
20 \text { volts } \\
1.67 \text { Amps } \\
36 \text { cells } \\
2 \mathrm{~kg} \\
450 \times 340 \times 13(\mathrm{~mm})\end{array}$ \\
\hline 2 & Charge Controller & $\begin{array}{l}\text { Model } \\
\text { Voltage } \\
\text { Current } \\
\text { Weight }\end{array}$ & $\begin{array}{l}\text { (PWM) } \\
12 \text {-volt Current } \\
5 \mathrm{amps} \\
0.5 \mathrm{~kg}\end{array}$ \\
\hline 3 & Battery & $\begin{array}{l}\text { Model } \\
\text { Current } \\
\text { Voltage } \\
\text { Cycle use } \\
\text { Standby use } \\
\text { Weight }\end{array}$ & $\begin{array}{l}\text { ISATECH } \\
8 \mathrm{Ah} \\
12 \text { volts } \\
14.1-14.4 \mathrm{~V} \\
13.5-13.8 \mathrm{~V} \\
2 \mathrm{~kg}\end{array}$ \\
\hline 4 & Pump & $\begin{array}{l}\text { Model } \\
\text { Pump Type } \\
\text { Max pressure } \\
\text { Current } \\
\text { Voltage } \\
\text { Power } \\
\text { Weight }\end{array}$ & $\begin{array}{l}\text { Flopump-Fl-2203 } \\
\text { Diaphragm pump } \\
0.45 \mathrm{MPa} \\
2 \mathrm{Amp} \\
12 \text { volts } \\
24 \text { Watts } \\
0.5 \mathrm{~kg}\end{array}$ \\
\hline 5 & De motor & $\begin{array}{l}\text { Type } \\
\text { Capacity: } \\
\text { Revolution per minute }\end{array}$ & $\begin{array}{l}\text { Brushless DC motor } \\
12 \mathrm{~V}, 2.0 \mathrm{~A} \\
\mathrm{RPM}: 0-3400\end{array}$ \\
\hline 6 & Liquid Storage Tank & $\begin{array}{l}\text { Capacity } \\
\text { Material }\end{array}$ & $\begin{array}{l}20 \text { litres } \\
\text { PVC }\end{array}$ \\
\hline 7 & Nozzle & $\begin{array}{l}\text { Number of nozzles } \\
\text { material } \\
\text { Model } \\
\text { type } \\
\text { Diameter } \\
\text { flow rate }\end{array}$ & $\begin{array}{l}3 \text { nozzle as tall as Steel Pipe } \\
\text { PL D-5 } \\
\text { flat fan } \\
1.3 \mathrm{~mm} \\
0.27-0.44(1 / \mathrm{min})\end{array}$ \\
\hline
\end{tabular}




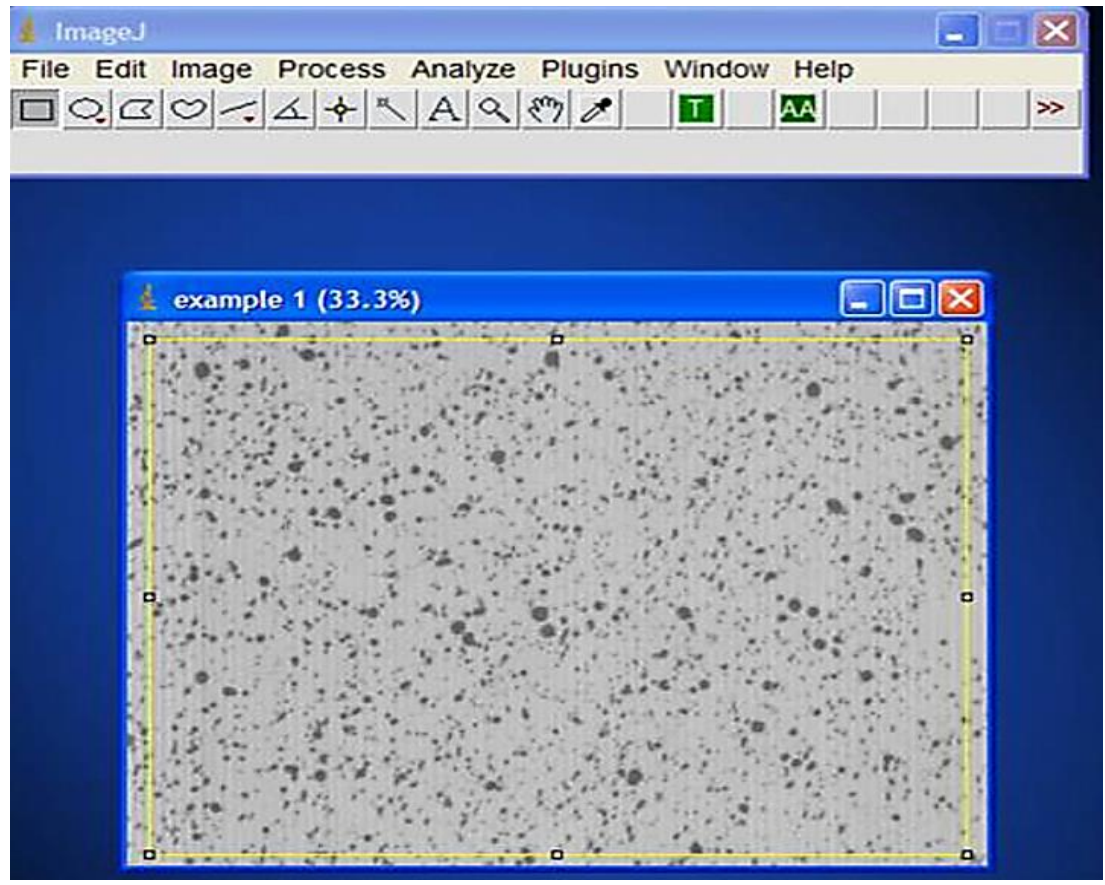

Fig 7. Heading for the page of ImageJ program used for analyze samples

Charging time (T) was calculated by taking the ratio rating of the battery in ampere-hour $\mathrm{AH})$ to the total current generated that is given from Equation (2).

Theoretical charging time $(\mathrm{T})=$
Rating of battery $(\mathrm{AH})$
Total current generated

\subsubsection{Back up battery time}

The discharging time while operating the sprayer at a different motor speed (2000, 2700 and $3400 \mathrm{rpm}$ ) that is given from Equation (3).

Theoretical discharging time $(\mathrm{T})=$ $\frac{\text { Power stored in battery }(\mathrm{w}-\mathrm{h})}{\text { Power consumed by motor }(\mathrm{w})}$

\subsubsection{Field efficiency}

The field area having $10 \mathrm{~m}$ length and 8 width was marked and spraying was carried out for field parameters such as swath width, the average operating speed, turning time, time of refilling the sprayer, time of preparation the solution was determined during the experiment.

Equation (4) calculates the rate of theoretical productivity (fed/h):

$$
\mathrm{P}_{\mathrm{t}}=\mathrm{S} \text {. }
$$

Where: $\mathrm{P}_{\mathrm{t}}=$ theoretical productivity, $\mathrm{S}=$ forward operator speed and $\mathrm{w}=$ swath width. Equation (5) calculates the rate of actual productivity (fed/h):

$$
\mathrm{P}_{\mathrm{a}=} \mathrm{P}_{\mathrm{t} \times} \eta
$$

Where: $\mathrm{P}_{\mathrm{a}}=$ actual productivity, $\mathrm{P}_{\mathrm{t}}=$ theoretical productivity, $\eta=$ field efficiency. Equation (6) calculates field efficiency $(\eta)$ :

$$
\eta=\frac{\mathrm{Pa}}{\mathrm{Pt}} \times 100 \%
$$


Equation (7) calculates the application rate: Application rate $($ liter $/$ fed $)=$

Volume collected (L) $\times$ Time for treating Time for discharging the liquid $(\mathrm{min}) \times$ Area
of test plot (fed)

\subsection{Instruments and Measurements}

Measuring devices used to run experiments in this study as follows:

- Measuring tape: A 10-meter tape was used to measure the distance to evaluate the operator speed.

- Stopwatch: Type: Casio JHS-20, with accuracy $1 / 100$ second.

- The multimeter: The type HANDSKIT DT9205A, was used to measure the ampere and the voltage of the battery then recorded the amber consumption for the motor and finally measure the volt of the battery.

- Tachometer: Laser beam was used to measure and monitor motor speed (rpm) on LCD display without load.

- Large protractor: for measuring nozzle spray tip angle.

\section{Results and Discussions}

This research aims to evaluate the operating of an electrically powered Knapsack sprayer with a rechargeable battery from a photovoltaic system to achieve the objectives.

\subsection{Experiment Laboratory}

\subsubsection{Effect of speed motor on number of droplets and the Coverage area ratio}

Tables 2 and 3 presented in Figs 8 and 9 show the effect of interaction between the different speed of the motor for Sprayer and three nozzles in multi nozzles boom sprayer on the concentration at equal spaces at right and left sides of the spray, so that experiment results showed as the following:

- Table 2 shows that the most suitable rpm achieved the highest number of droplets with $3400 \mathrm{rpm}$ and the highest value was 146 drops at the spray center.
- Table 3 shows that the most suitable rpm achieved the highest coverage ratio with $3400 \mathrm{rpm}$ and the highest value was $27.9 \%$ at the spray center.

- The results also show that the deposition decreases Away from the spray center on both side.

\subsubsection{Effect of motor speed on flow rate for} the nozzles in the multi-nozzle boom sprayer

Fig 10 shows that increasing the motor speed leads to increased flow rate for the nozzles in the multi-nozzle boom. On the other side, the discharging was ranged from 0.85$1.33 \mathrm{l} / \mathrm{min}$ at the motor speed changed from $2000-3400 \mathrm{rpm}$ respectively. From figure 11 the relationship between the flow rate for the nozzles "Q" and the motor speed "s" is $\mathrm{Q}=$ $0.0004 \mathrm{~s}$.

3.1.3 Effect of motor speed on the spray angle for the flat fan nozzles in the boom sprayer

Fig 11 shows that increasing the speed motor leads to an increasing angle of the flat fan nozzles in the boom sprayer (Bateman 2004). Also, the angle of the sprayer cone was ranged from $76^{\circ}-86^{\circ}$ at the motor speed changed from $2000-3400 \mathrm{rpm}$, respectively.

\subsection{Field experiments testes}

\subsubsection{Battery recharging time}

State of the battery during charging according to the electric power output from the panel is given to the battery to store the electricity depending upon charge controller prevents the battery from overcharging and it increases the battery lifetime.

- Theoretical time for recharging the battery using Equation 1 and 2 was 290 min.

- Experiments testes shows that the duration for recharging the battery based on the experimentation, it takes $330 \mathrm{~min}$., from 8:00 am to $1: 30 \mathrm{pm}$ to charge completely from $10.55-13.85 \mathrm{~V}$. 
Table 2. Mean values of droplets number $\left(\right.$ droplet $\left./ \mathrm{cm}^{2}\right)$ at different speed

\begin{tabular}{|l|c|c|c|c|c|}
\hline \multirow{2}{*}{ motor Speed } & \multicolumn{5}{|c|}{ Side (lateral) distances (cm) } \\
\cline { 2 - 6 } & $\mathbf{- 8 0}$ & $\mathbf{- 4 0}$ & $\mathbf{0 . 0}$ & $\mathbf{4 0}$ & $\mathbf{8 0}$ \\
\hline T1 $(2000 \mathrm{rpm})$ & 30 & 41 & 42 & 36.6 & 30 \\
\hline T2 $(2700 \mathrm{rpm})$ & 55 & 64 & 83 & 78 & 66 \\
\hline T3 $(3400 \mathrm{rpm})$ & 119 & 120 & 146 & 127 & 124 \\
\hline
\end{tabular}

Table 3. Mean values of area coverage at different speed

\begin{tabular}{|l|c|c|c|c|c|}
\hline \multirow{2}{*}{ motor Speed } & \multicolumn{5}{|c|}{ Side (lateral) distances (cm) } \\
\cline { 2 - 6 } & $\mathbf{- 8 0}$ & $\mathbf{- 4 0}$ & $\mathbf{0 . 0}$ & $\mathbf{4 0}$ & $\mathbf{8 0}$ \\
\hline T1 $(2000 \mathrm{rpm})$ & 13 & 17.7 & 20.5 & 13.9 & 13.8 \\
\hline T2 $(2700 \mathrm{rpm})$ & 21.5 & 22 & 24.4 & 24 & 21.6 \\
\hline T3 $(3400 \mathrm{rpm})$ & 25 & 27 & 28 & 27.4 & 26.3 \\
\hline
\end{tabular}

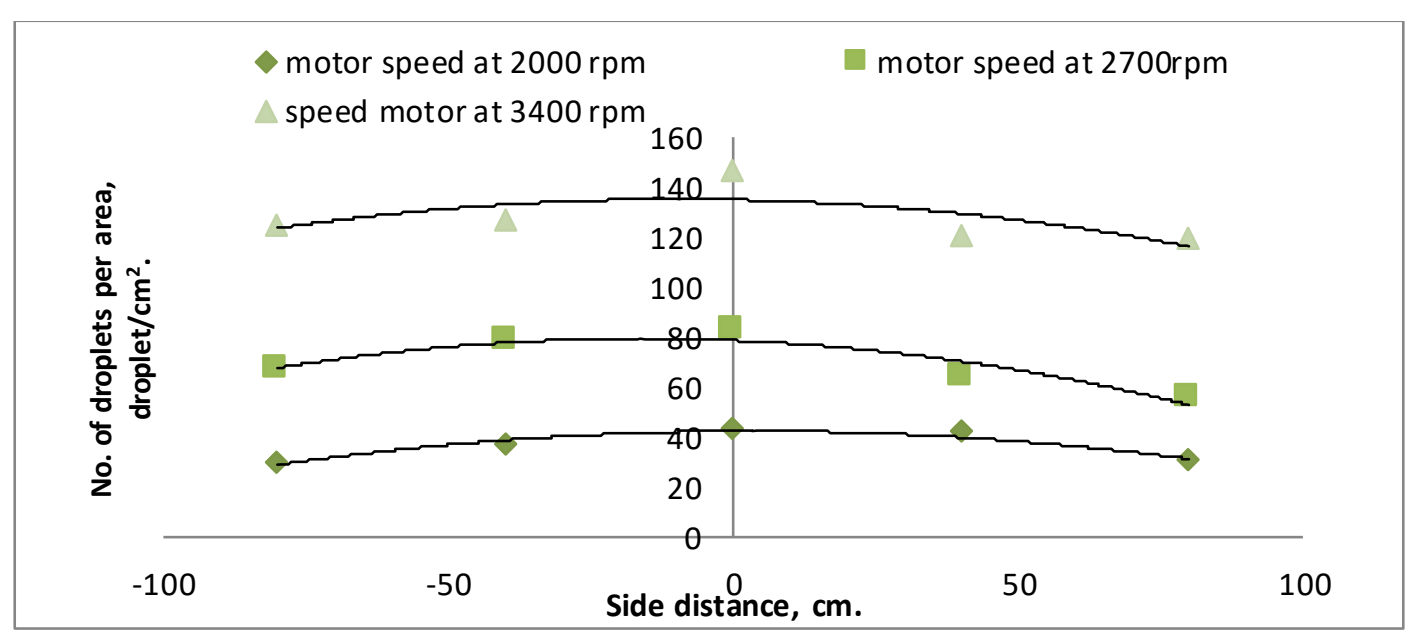

Fig 8. Effect of motor speed on number of droplets per area

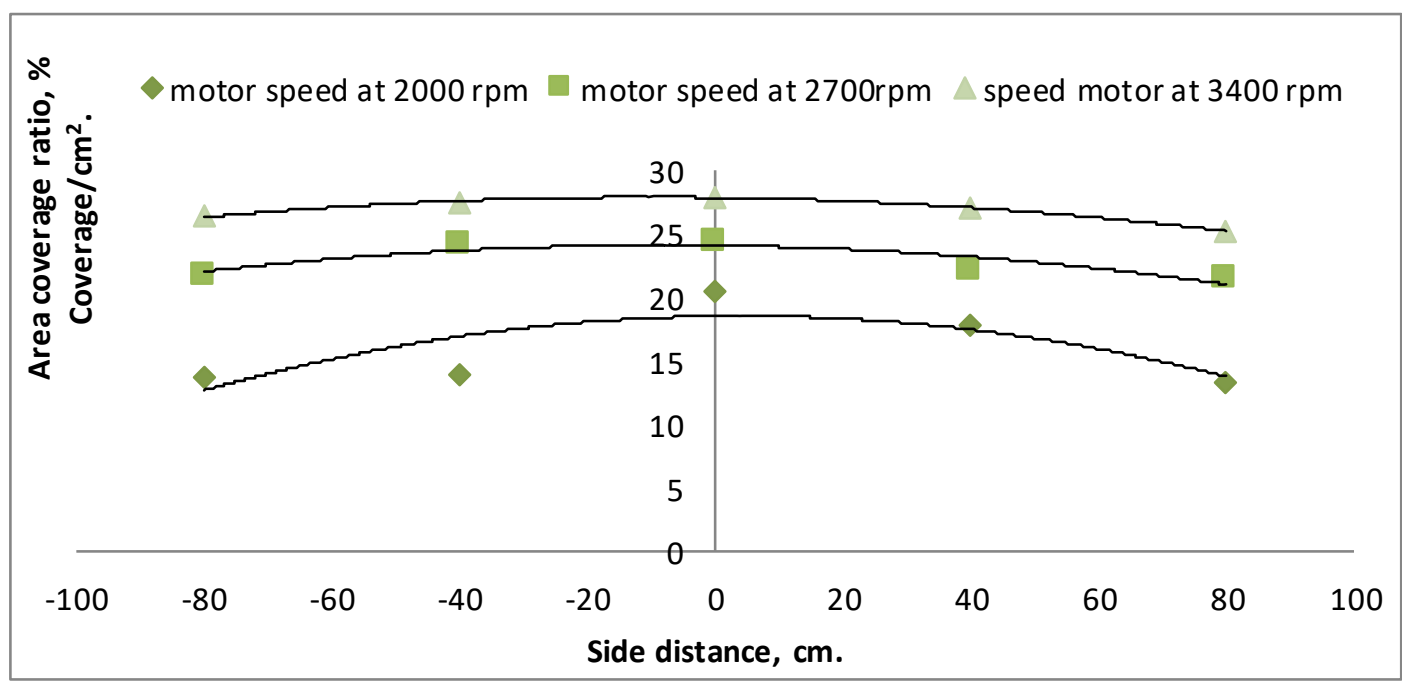

Fig 9. Effect of motor speed on area covera ge ratio 


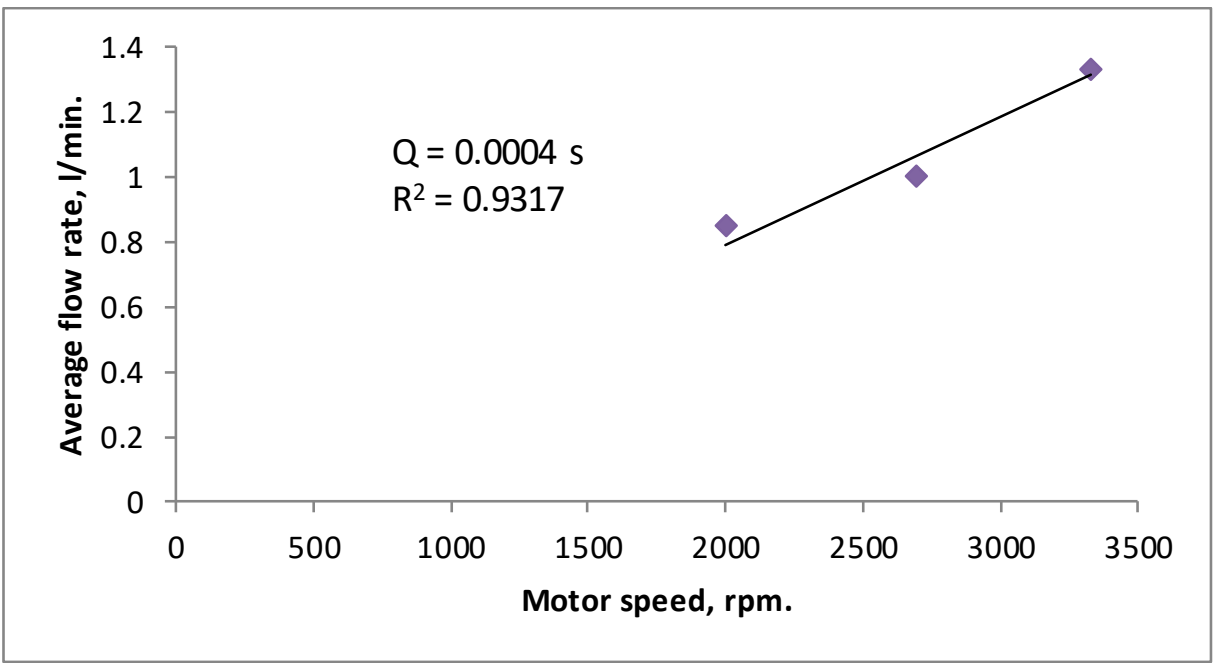

Fig 10. Effect of motor speed on value of flow rate for the nozzles

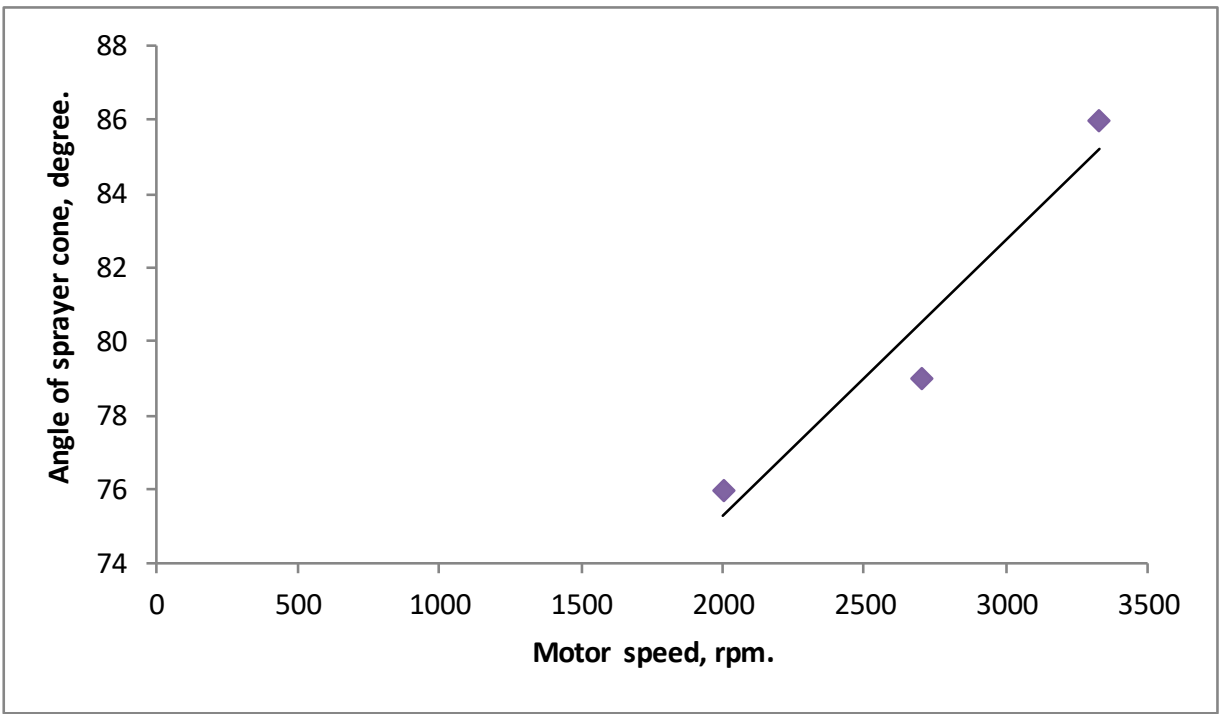

Fig 11. Effect of motor speed on tip angle for cone (degree)

\subsubsection{Back up battery time of sprayer}

Fig 12 shows the battery discharging time while voltage condescension from 13.85 to $10.55 \mathrm{v}$ at different motor speeds. The battery discharging times were 540, 300 and $240 \mathrm{~min}$., when the motor pulled 0.85 Ampere at 2000 rpm, 1.4 Ampere at $2700 \mathrm{rpm}$ and 1.4 Ampere at $3400 \mathrm{rpm}$, respectively.

\subsubsection{Field efficiency and performance rate results}

To calculate the field efficiency, steps were as followes:

- Average of forward speed according to tests $=0.71 \mathrm{~m} / \mathrm{s}=2.5 \mathrm{~km} / \mathrm{h}$,

- Width of spray swath $=2 \mathrm{~m}$,

- Plot area $=8 \times 10=80 \mathrm{~m}^{2}$,

- According to Equation (4), 


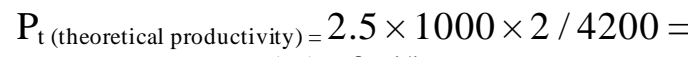
$1.19 \mathrm{fed} / \mathrm{h}$

- Theoretical time of the treatment plot area $" \mathrm{t}_{1} "=0.96 \mathrm{~min}=57.6 \mathrm{sec}$,

$$
\text { Actual time }=\mathrm{t}_{1}+\mathrm{t}_{2}+\mathrm{t}_{3}+\mathrm{t}_{4},
$$

Where, $\mathrm{t}_{1}=$ spraying time, $\mathrm{t}_{2}=$ turning time, $\mathrm{t}_{3}=$ fill up the tank time and $t_{4}=$ over lapping time. Actual time $=57.6+15+15+2.8=90.4 \mathrm{sec}$ $=1.5 \mathrm{~min}$
Field efficiency $=\frac{\text { Theoretical time }}{\text { Actual time }} \times 100=$
$\frac{0.96}{1.5} \times 100=63.71 \%$.

- Actual field capacity according to Equation (4),

$$
P_{a}=P_{t \times} \eta=1.19 \times 0.6575=0.758 \mathrm{fed} / \mathrm{h} .
$$

Performance rate $=\mathrm{Pa} \times \mathrm{h}=0.758 \times 6=4.5$ fed/day

Where, $\mathrm{h}=$ No. of hours daily work, (assume $\mathrm{h}=6)$.

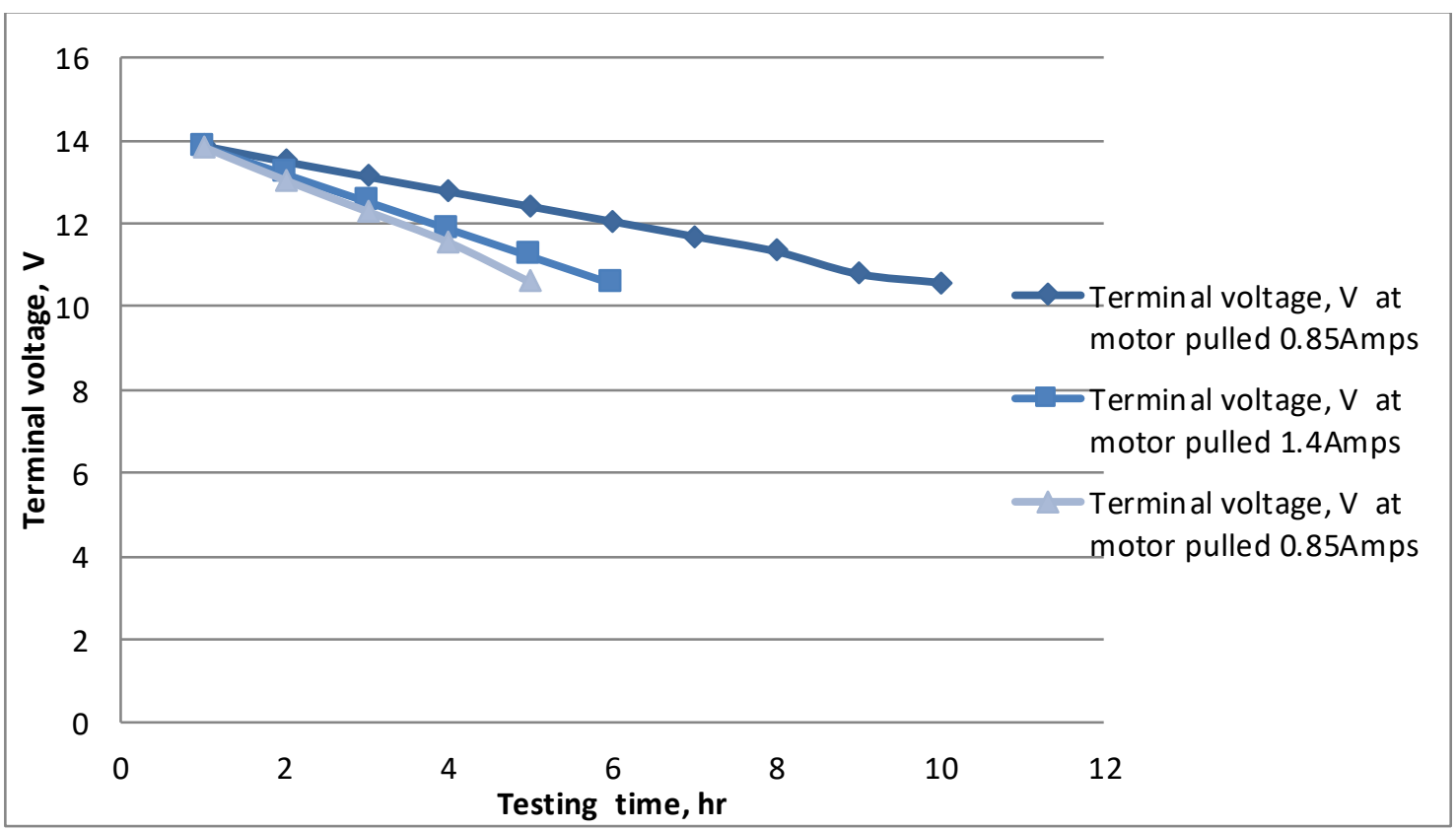

Fig 12. Testing state of the battery for estimating discharging the time with 2000,2700 and $3400 \mathrm{rpm}$

\section{Conclusion}

The objective of this study used to be in accordance with develop a solar-powered sprayer to utilize solar energy as its source of power for operating, the following conclusions is as the follow: The spray intensity was significantly increased with nozzle discharging. Maximum spray deposition occurred at the center of the spray and the deposition of droplets decreased with width of spray. A proposed system made it possible the use of easy or advantageous principle over storing sun energy among battery through a constant supply of voltage from solar charge controller and then with the use of selected pump then lifts the liquid from the tank via one outlet and supplies to the boom sprayer. Solar sprayers are concerning large advantage, due to the fact it is easy into building with convenient weight. The machine has minimum welded parts, that makes assembly, disassembly pretty easy and the 
sprayer portable. This technology is most suitable for Energy Alternate agricultural machine for powering sprayers and the same technique and technology can also be extended for all types of agricultural sprayers. The lightweight advantage makes maneuverability easy.

From the previous, it could be recommended that the capacity of the battery can be increased in the future depending upon the energy requirements. Further lookup in accordance with improves overall performance rate by using the use of just appropriate DC motor.

\section{References}

Abdulmumuni B, Azeez RO, Okpara IN, Fanifosi JO, Ologunye OB (2020) Design and fabrication and testing movable solar operated sprayer for farming operation. IJMET 11, 6-14.

Aboegela MA, Elmeadawy MI, Islam ME, ElSebaee IM, El-Fakhrany WB (2019) Development a knapsack sprayer powered by photovoltaic panel. Journal of Soil Sciences and Agricultural Engineering 12, 907-912.

Abu-Aligah M (2011) Design of photovoltaic water pumping system and compare it with diesel powered pump. Jordan Journal of Mechanical and Industrial Engineering 5, 273-280.

Abu Eldahab YE, Saad NH, Zekry A (2016) Enhancing the design of battery charging controllers for photovoltaic systems. Renew Sustain Energy Rev 58, 646-655.

Ashutosh M, Neetu B, Padam S (2019) Development of solar operated sprayer for small scale farmers. International Journal of Current Microbiology and Applied Sciences 2, 2593-2596.
Bateman R (2004) The use of narrow-angle cone nozzles to spray cocoa pods and other slender biological targets. Crop Protection 23, 989-999.

Fox RD, Derksen RC, Cooper JA, Krause CR, Ozkan HE (2003) Visual and image system measurement of spray deposits using watersensitive paper. Applied Engineering in Agriculture 19, 549-552.

Kannaiyan K, Sadr R (2014) Effect of fuel properties on spray characteristics of alternative jet fuels using global sizing velocimetry. Atomization and Sprays 24, 575597.

Meral ME, Dincer F (2011) Review of the factors affecting operation and efficiency of photovoltaic based electricity generation systems. Renewable and Sustainable Energy Reviews 15, 2176-2184.

Theriault R, Salyani M, Panneton B (2001) Spray distribution and recovery in citrus application with a recycling sprayer. Trans. ASAE 44, 1083-1088.

Vinay SDK (2016) Design and development of solar photovoltaic based power sprayer for agricultural use. Article in Annals of Arid Zone 55, 51-57.

Wolf RE (2003) Assessing the ability of droplet scan to analyze spray droplets from a ground operated sprayer. Appl Eng Agric 19, 525-530.

Xing Y, Ma EWM, Tsui KL, Pecht M (2011) Battery Management Systems in Electric and Hybrid Vehicles. Energies 4, 1840-1857. 